\title{
Nocardia keratitis: amikacin nonsusceptibility, risk factors, and treatment outcomes
}

\author{
Ethan Adre ${ }^{1,2}$, Jorge Maestre-Mesa ${ }^{3,4}$, Heather Durkee ${ }^{2}$, Alejandro Arboleda ${ }^{1,2}$, Harry Flynn $\mathrm{Jr}^{4}$, \\ Guillermo Amescua ${ }^{2,4}$, Jean-Marie Parel ${ }^{2,4}$ and Darlene Miller ${ }^{3,4^{*}}$ (D)
}

\begin{abstract}
Purpose: To report the increasing trends in Nocardia keratitis species diversity and in vitro antibiotic susceptibility, to demonstrate contact lens wear as a risk factor, and to report visual acuity outcomes after treatment.

Methods: A retrospective clinical case series was performed at a single academic referral center which identified 26 patients with culture-confirmed Nocardia keratitis between 2014 and 2021. A combination of conventional microbiology and molecular techniques were used to identify isolates. Antibiotic susceptibilities were determined using both commercial and in-house laboratory methods. Microbiology and electronic medical records were used to characterize patients' clinical profiles.

Results: Patients' median age was 32.5 years with a 2:1 male to female ratio. Eighty-four percent $(n=21 / 25)$ of patients were diagnosed within two weeks of symptom onset. Nocardia amikacinitolerans $(n=11 / 26)$ was the most recovered Nocardia isolate among study patients. Sixty-four percent $(n=16 / 25)$ of all isolates, including all $11 \mathrm{~N}$. amikacinitolerans isolates, were resistant to amikacin. All isolates were susceptible to trimethoprim sulfamethoxazole. Contact lens wear was the leading identified risk factor $(n=23 / 26)$ in this population. Median time to resolution was 44 days $(n=23$, range: $3-190$ days). Seventy-one percent of patients $(n=15 / 21)$ had a final visual acuity of $20 / 40$ or better.

Conclusion: Amikacin resistant Nocardia isolates were the majority in the current study. Trimethoprim sulfamethoxazole may be the preferred alternative antibiotic treatment based on in vitro susceptibilities. Contact lens wear was the major risk factor for Nocardia keratitis in South Florida. Overall visual acuity treatment outcomes of patients were favorable.
\end{abstract}

Keywords: Nocardia keratitis, Antibiotic resistance, Contact-lens keratitis

\section{Background}

Nocardia are a heterogenous group of aerobic, branching, gram positive, weakly acid-fast bacteria commonly found in dust, decaying vegetable matter, and aquatic environments [1]. Ocular nocardiosis most often

\footnotetext{
* Correspondence: dmiller@med.miami.edu

${ }^{3}$ Ocular Microbiology Laboratory, Anne Bates Leach Eye Center, Bascom Palmer Eye Institute, University of Miami Miller School of Medicine, McKnight Research Pavilions, Rm 103A,1638 NW 10th Avenue, Miami, FL 33136, USA ${ }^{4}$ Department of Ophthalmology, Bascom Palmer Eye Institute, University of Miami Miller School of Medicine, Miami, FL, USA

Full list of author information is available at the end of the article
}

presents as keratitis [2,3]. Nocardia keratitis is a rare, chronic, debilitating cause of keratitis historically associated with trauma [2-6]. Global prevalence is below $2 \%$ $[2,5]$. It is difficult to diagnose and treat due to a combination of diverse species' presentations and speciesspecific response to commonly used topical antibiotics.

Topical amikacin is the current standard of care for medical management of Nocardia keratitis [5, 7]. However, isolates are increasingly diverse and may differ by geography, patient population, and antimicrobial susceptibility $[1,2,5]$. Data on clinical presentation, risk factors, species diversity, and medical management have 
Table 1 Clinical Characteristics of Nocardia Keratitis Cases (2014-2021)

\begin{tabular}{|c|c|c|c|c|c|c|c|c|c|}
\hline Case & $\begin{array}{l}\text { Age/ } \\
\text { Sex }\end{array}$ & $\begin{array}{l}\text { Risk } \\
\text { Factors }\end{array}$ & $\begin{array}{l}\text { Days to } \\
\text { Presentation }\end{array}$ & $\begin{array}{l}\text { Presenting } \\
\text { Visual } \\
\text { Acuity }\end{array}$ & Presentation & $\begin{array}{l}\text { Days to } \\
\text { Resolution }\end{array}$ & $\begin{array}{l}\text { Last } \\
\text { Follow- } \\
\text { up Visual } \\
\text { Acuity }\end{array}$ & Species & $\begin{array}{l}\text { Topical } \\
\text { Steroid } \\
\text { Use }\end{array}$ \\
\hline 1 & $49 / F$ & $\begin{array}{l}\text { Contact } \\
\text { lens } \\
\text { wear }\end{array}$ & 5 & $20 / 20$ & $\begin{array}{l}1.4 \mathrm{~mm} \text { corneal epithelial defect w/ } \\
\text { underlying infiltrate }\end{array}$ & 19 & $20 / 20$ & $\begin{array}{l}\text { Nocardia } \\
\text { beijingensis/ } \\
\text { pneumoniael } \\
\text { araoensis }\end{array}$ & No \\
\hline 2 & $24 / F$ & $\begin{array}{l}\text { Contact } \\
\text { lens } \\
\text { wear; } \\
\text { trauma }\end{array}$ & 14 & $20 / 25$ & $\begin{array}{l}\text { Inferior patchy infiltrate } 5 \mathrm{~mm} \times 2.5 \mathrm{~mm} \\
\text { with patchy overlying corneal epithelial } \\
\text { defects }\end{array}$ & 56 & $20 / 20$ & $\begin{array}{l}\text { Nocardia } \\
\text { amikacinitolerans }\end{array}$ & No \\
\hline 3 & $\begin{array}{l}64 / \\
M\end{array}$ & $\begin{array}{l}\text { Contact } \\
\text { lens } \\
\text { wear } \\
\text { (BCL) }\end{array}$ & 14 & $\begin{array}{l}\text { No Light } \\
\text { Perception }\end{array}$ & $\begin{array}{l}\text { Central } 1.6 \mathrm{~mm} \times 1.6 \mathrm{~mm} \text { white chalky } \\
\text { infiltrate }\end{array}$ & $\begin{array}{l}\text { Lost to } \\
\text { Follow Up }\end{array}$ & $\begin{array}{l}\text { No Light } \\
\text { Perception }\end{array}$ & Nocardia testacea & Yes \\
\hline 4 & $20 / F$ & $\begin{array}{l}\text { Contact } \\
\text { lens } \\
\text { wear }\end{array}$ & 19 & $20 / 70$ & $\begin{array}{l}2.2 \mathrm{~mm} \times 2.2 \mathrm{~mm} \text { inferonasal round } \\
\text { patch of irregular multifocal white } \\
\text { infiltrates, minimal corneal thinning, } \\
\text { irregular overlying punctate corneal } \\
\text { staining, no dendrites }\end{array}$ & 54 & $20 / 25$ & $\begin{array}{l}\text { Nocardia } \\
\text { beijingensis }\end{array}$ & No \\
\hline 5 & $\begin{array}{l}25 / \\
M\end{array}$ & $\begin{array}{l}\text { Contact } \\
\text { lens } \\
\text { wear }\end{array}$ & 10 & $20 / 40-2$ & $\begin{array}{l}1 \mathrm{~mm} \times 1.4 \mathrm{~mm} \text { white fluffy opacity } \\
\text { with irregular borders; satellite sub } 1 \\
\mathrm{~mm} \text { round lesion, no staining, no } \\
\text { neovascularization }\end{array}$ & 44 & $20 / 70$ & $\begin{array}{l}\text { Nocardia } \\
\text { amikacinitolerans }\end{array}$ & No \\
\hline 6 & $\begin{array}{l}21 / \\
M\end{array}$ & $\begin{array}{l}\text { Contact } \\
\text { lens } \\
\text { wear }\end{array}$ & 14 & $20 / 30$ & $\begin{array}{l}\text { Irregular epithelium with } \\
\text { pseudodendritic appearance } 5 \mathrm{~mm} \\
\text { non-continuously, scattered anterior } \\
\text { stromal infiltrate with pannus }\end{array}$ & 39 & $20 / 40-1$ & $\begin{array}{l}\text { Nocardia } \\
\text { amikacinitolerans }\end{array}$ & Yes \\
\hline 7 & $\begin{array}{l}66 / \\
M\end{array}$ & Trauma & 7 & $0.5 / 200$ & $\begin{array}{l}2 \mathrm{~mm} \times 2 \mathrm{~mm} \text { corneal ulcer with } \\
\text { corneal epithelial defect and } \\
\text { Descemet's folds }\end{array}$ & 20 & $0.5 / 200$ & Nocardia harenae & Yes \\
\hline 8 & $\begin{array}{l}55 / \\
M\end{array}$ & $\begin{array}{l}\text { Contact } \\
\text { lens } \\
\text { wear } \\
\text { (soft); } \\
\text { trauma }\end{array}$ & 10 & $20 / 25$ & Inferior soupy $1.5 \mathrm{~mm}$ circular ulcer & $\begin{array}{l}\text { Lost to } \\
\text { Follow Up }\end{array}$ & $\begin{array}{l}\text { Lost to } \\
\text { Follow Up }\end{array}$ & $\begin{array}{l}\text { Nocardia } \\
\text { amikacinitolerans }\end{array}$ & No \\
\hline 9 & $56 / F$ & $\begin{array}{l}\text { Contact } \\
\text { lens } \\
\text { wear }\end{array}$ & 5 & $20 / 70$ & $\begin{array}{l}7 \text { discrete, round corneal epithelial } \\
\text { defects with anterior stromal infiltrate } \\
\text { underlying }\end{array}$ & 6 & $20 / 40$ & $\begin{array}{l}\text { Nocardia } \\
\text { amikacinitolerans }\end{array}$ & No \\
\hline 10 & $\begin{array}{l}19 / \\
M\end{array}$ & Trauma & 3 & $20 / 20$ & $\begin{array}{l}\sim 0.9 \mathrm{~mm} \times 0.9 \mathrm{~mm} \text { patchy infiltrate, } \\
\text { edges are more opaque and not } \\
\text { contiguous, focal mild Descemet's } \\
\text { folds, surrounding infiltrate looks dense }\end{array}$ & 49 & $20 / 20$ & Nocardia farcinica & No \\
\hline 11 & $\begin{array}{l}24 / \\
M\end{array}$ & $\begin{array}{l}\text { Contact } \\
\text { lens } \\
\text { wear }\end{array}$ & 70 & $20 / 30$ & $\begin{array}{l}\text { 2+ infiltrate, } 4.5 \mathrm{~mm} \times 2 \mathrm{~mm} \text { ring } \\
\text { infiltrate, no hypopyon }\end{array}$ & 45 & $20 / 30$ & $\begin{array}{l}\text { Nocardia } \\
\text { beijingensis/ } \\
\text { pneumoniae }\end{array}$ & No \\
\hline 12 & $\begin{array}{l}38 / \\
M\end{array}$ & $\begin{array}{l}\text { Contact } \\
\text { lens } \\
\text { wear } \\
\text { (soft) }\end{array}$ & 13 & $20 / 400$ & $\begin{array}{l}\text { Corneal epithelial defect } 2 \mathrm{~mm} \times 3 \mathrm{~mm} \text {, } \\
\text { questionable infiltrate on borders, no } \\
\text { satellite (suspected HSV keratitis), } \\
\text { corneal epithelial defect with } \\
\text { neovascular limbal vessels. Central haze } \\
\text { and infiltrate, mild punctate stain }\end{array}$ & 190 & $20 / 30$ & $\begin{array}{l}\text { Nocardia } \\
\text { arthritidis }\end{array}$ & Yes \\
\hline 13 & $\begin{array}{l}16 / \\
M\end{array}$ & $\begin{array}{l}\text { Contact } \\
\text { lens } \\
\text { wear }\end{array}$ & 14 & $20 / 30$ & $\begin{array}{l}2.5 \mathrm{~mm} \text { clusters of superficial infiltrates } \\
\text { without thinning }\end{array}$ & 43 & $20 / 25$ & $\begin{array}{l}\text { Nocardia } \\
\text { amikacinitolerans }\end{array}$ & Yes \\
\hline 14 & $\begin{array}{l}52 / \\
M\end{array}$ & $\begin{array}{l}\text { Contact } \\
\text { lens } \\
\text { wear }\end{array}$ & 30 & $20 / 20$ & Ring infiltrate with central haze & 64 & $20 / 20$ & Nocardia veterana & Yes \\
\hline 15 & $\begin{array}{l}30 / \\
M\end{array}$ & $\begin{array}{l}\text { Contact } \\
\text { lens }\end{array}$ & 10 & $20 / 25$ & $\begin{array}{l}\text { Large lesion with raised edges and } \\
\text { scattered staining }\end{array}$ & 47 & $20 / 20$ & $\begin{array}{l}\text { Nocardia } \\
\text { amikacinitolerans }\end{array}$ & No \\
\hline
\end{tabular}


Table 1 Clinical Characteristics of Nocardia Keratitis Cases (2014-2021) (Continued)

\begin{tabular}{|c|c|c|c|c|c|c|c|c|c|}
\hline Case & $\begin{array}{l}\text { Age/ } \\
\text { Sex }\end{array}$ & $\begin{array}{l}\text { Risk } \\
\text { Factors }\end{array}$ & $\begin{array}{l}\text { Days to } \\
\text { Presentation }\end{array}$ & $\begin{array}{l}\text { Presenting } \\
\text { Visual } \\
\text { Acuity }\end{array}$ & Presentation & $\begin{array}{l}\text { Days to } \\
\text { Resolution }\end{array}$ & $\begin{array}{l}\text { Last } \\
\text { Follow- } \\
\text { up Visual } \\
\text { Acuity }\end{array}$ & Species & $\begin{array}{l}\text { Topical } \\
\text { Steroid } \\
\text { Use }\end{array}$ \\
\hline & & wear & & & & & & & \\
\hline 16 & $\begin{array}{l}21 / \\
M\end{array}$ & $\begin{array}{l}\text { Contact } \\
\text { lens } \\
\text { wear }\end{array}$ & 17 & $20 / 30$ & $\begin{array}{l}4.6 \mathrm{~mm} \times 4.4 \mathrm{~mm} \text { area of stromal } \\
\text { infiltrate with discrete white opacities, } \\
\text { white ring at the border } 360 \text { that stains, } \\
\text { otherwise no staining. Some enlarged } \\
\text { corneal nerves. No endothelial plaque }\end{array}$ & 137 & $20 / 25$ & $\begin{array}{l}\text { Nocardia } \\
\text { amikacinitolerans }\end{array}$ & Yes \\
\hline 17 & $\begin{array}{l}17 / \\
M\end{array}$ & $\begin{array}{l}\text { Contact } \\
\text { lens } \\
\text { wear } \\
\text { (soft) }\end{array}$ & 5 & $20 / 30$ & $\begin{array}{l}1 \mathrm{~mm} \times 1 \mathrm{~mm} \text { ulcer with small infiltrate } \\
\text { at margin of lesion and overlying } \\
\text { epithelial defect }\end{array}$ & 9 & $20 / 20$ & $\begin{array}{l}\text { Nocardia } \\
\text { amikacinitolerans }\end{array}$ & No \\
\hline 18 & $52 / F$ & $\begin{array}{l}\text { Contact } \\
\text { lens } \\
\text { wear }\end{array}$ & 4 & $20 / 20$ & $\begin{array}{l}\text { Inferotemporal, inferior and superior } \\
\text { pinpoint infiltrates, very pinpoint } \\
\text { corneal epithelial defect }\end{array}$ & 50 & $20 / 20$ & $\begin{array}{l}\text { Nocardia } \\
\text { arthritidis }\end{array}$ & Yes \\
\hline 19 & $36 / F$ & $\begin{array}{l}\text { Contact } \\
\text { lens } \\
\text { wear }\end{array}$ & 10 & $20 / 25+1$ & $\begin{array}{l}\text { Central corneal ulcer, } 1.5 \mathrm{~mm} \times 1.6 \mathrm{~mm} \text {, } \\
\text { with } 25 \% \text { thinning, underlying } \\
\text { Descemet's folds, diffuse epithelial } \\
\text { edema, peripheral staining of ulcer } \\
\text { edges }\end{array}$ & $\begin{array}{l}\text { Lost to } \\
\text { Follow Up }\end{array}$ & $20 / 25-2$ & $\begin{array}{l}\text { Nocardia } \\
\text { amikacinitolerans/ } \\
\text { beijingensis }\end{array}$ & Yes \\
\hline 20 & $\begin{array}{l}35 / \\
M\end{array}$ & $\begin{array}{l}\text { Contact } \\
\text { lens } \\
\text { wear }\end{array}$ & 9 & $20 / 400$ & $\begin{array}{l}\text { Pannus, multiple small infiltrates } 0.2 \\
\mathrm{~mm} \times 0.2 \mathrm{~mm} \text { with overlaying corneal } \\
\text { epithelial defect arranged roughly in a } \\
\text { circle (nonconfluent), no dendrites }\end{array}$ & 134 & $20 / 100$ & $\begin{array}{l}\text { Nocardia } \\
\text { asteroides } \\
\text { complex }\end{array}$ & No \\
\hline 21 & $\begin{array}{l}27 / \\
M\end{array}$ & $\begin{array}{l}\text { Contact } \\
\text { lens } \\
\text { wear }\end{array}$ & 14 & 20/100 & $1 \mathrm{~mm} \times 1 \mathrm{~mm}$ with infiltrate & 7 & $20 / 80$ & $\begin{array}{l}\text { Nocardia } \\
\text { endophytica }\end{array}$ & Yes \\
\hline 22 & $\begin{array}{l}16 / \\
M\end{array}$ & $\begin{array}{l}\text { Contact } \\
\text { lens } \\
\text { wear }\end{array}$ & Not Available & 20/300 & $\begin{array}{l}2.3 \mathrm{~mm} \times 2.4 \mathrm{~mm} \text { superficial corneal } \\
\text { lesion, with pseudo dendrites } \\
\text { emanating from the center of the } \\
\text { lesion }\end{array}$ & 49 & $20 / 20$ & $\begin{array}{l}\text { Nocardia } \\
\text { beijingensis }\end{array}$ & Yes \\
\hline 23 & $23 / F$ & $\begin{array}{l}\text { Contact } \\
\text { lens } \\
\text { wear }\end{array}$ & 7 & $20 / 25$ & $\begin{array}{l}2.9 \mathrm{~mm} \times 2.1 \mathrm{~mm} \text { infiltrate concentrated } \\
\text { on periphery of lesion. Scattered small } \\
\text { corneal epithelial defects around } \\
\text { periphery of lesion. Minimal cornea } \\
\text { edema surrounding. }\end{array}$ & 25 & $20 / 40$ & $\begin{array}{l}\text { Nocardia } \\
\text { amikacinitolerans }\end{array}$ & No \\
\hline 24 & $\begin{array}{l}56 / \\
M\end{array}$ & Trauma & 7 & $20 / 40$ & $\begin{array}{l}\text { Dendriform corneal epithelial defect } \\
\text { with underlying opacity outside visual } \\
\text { axis }<1 \mathrm{~mm} \text { in size }\end{array}$ & 16 & $20 / 50$ & $\begin{array}{l}\text { Nocardia } \\
\text { amikacinitolerans }\end{array}$ & No \\
\hline 25 & $38 / F$ & $\begin{array}{l}\text { Contact } \\
\text { lens } \\
\text { wear }\end{array}$ & 7 & $20 / 30-2$ & $\begin{array}{l}1.8 \mathrm{~mm} \text { epithelial defect with anterior } \\
\text { stromal infiltrate at edges and } \\
\text { surrounding haze. No thinning }\end{array}$ & 3 & $20 / 40$ & $\begin{array}{l}\text { Nocardia } \\
\text { bhagyanarayanae }\end{array}$ & No \\
\hline 26 & $\begin{array}{l}54 / \\
M\end{array}$ & $\begin{array}{l}\text { Contact } \\
\text { lens } \\
\text { wear }\end{array}$ & 7 & $20 / 70$ & Not available & 51 & $20 / 40$ & $\begin{array}{l}\text { Nocardia } \\
\text { beijingensis }\end{array}$ & Yes \\
\hline
\end{tabular}

been reported predominantly for patient populations outside the United States. The purpose of the current study is to characterize and report Nocardia keratitis species diversity and in vitro antibiotic susceptibility, to identify contact lens wear as a risk factor among Nocardia keratitis patients, and to report visual acuity outcomes after treatment.

\section{Methods}

The current study is a retrospective, single center, clinical case series. Institutional Review Board (IRB) approval was obtained from the University of Miami Miller School of Medicine Sciences Subcommittee for the Protection of Human Subjects and the research adhered to the Tenets of the Declaration of Helsinki (IRB Protocol Study ID \#20070960). Clinical data was collected and analyzed for 26 patients presenting with Nocardia keratitis between January 2014 and September 2021. Extracted data included patient demographics, risk factors, days from symptom onset to presentation, presenting best corrected visual acuity (BCVA), days to resolution, BCVA at last follow-up, and topical steroid use. 
A combination of conventional (culture, biochemical assay), molecular (rDNA sequencing), and/or reference laboratories were used to confirm and speciate the Nocardia isolates. Antibiotic susceptibility was determined using a combination of Etests (BioMerieux, Raleigh, NC), commercial laboratories, and the Sensititre Rapmyco microdilution panel (Thermo Fisher Scientific, Waltham, MA). Minimal inhibitory concentrations (MIC) interpretive standards for susceptible and resistant strains were in accordance with manufacturers and Clinical Laboratory Standards Institute (CLSI, Wayne, PA) guidelines [8]. Nonsusceptibility included both intermediate and resistant isolates.

\section{Results}

The current study includes 26 eyes of 26 patients. Overall, the median age was 32.5 years $(n=26$; range: $16-66$ years) and included 17 male and 9 female patients. A diverse group $(n=13)$ of Nocardia species were recovered among this patient population. $N$. amikacinitolerans (Fig. 1) was the most frequent isolate $(n=11,42.3 \%)$ followed by $N$. beijingensis $(n=3,11.5 \%), N$. arthritidis $(n=2,7.7 \%)$, and one each (3.8\%) of remaining 10 isolates detailed in Table 1. Patients with $N$. amikacinitolerans keratitis were younger with a median age of 24 years ( $n=11$; range: $16-56$ years).

Complete susceptibility data is summarized in Table 2; in vitro susceptibility daya was not available for a total of one isolate. Amikacin nonsusceptibility was determined in $64 \%$ of isolates $(n=16 / 25)$. All 11 of the $N$. amikacinitolerans isolates were resistant to amikacin and constituted $73.3 \%(n=11 / 15)$ of the amikacin nonsusceptible isolates documented during the study. Of note, $100 \%$ of isolates were susceptible to either trimethoprim sulfamethoxazole or linezolid.

Mean presenting BCVA $(n=25)$ was $20 / 60 \pm 2.3$ lines. (Table 1). At presentation, $64 \%(n=16 / 25)$ of the patients



Fig. 1 Patient with a Nocardia amikacinitolerans infiltrate. Classically described wreath-like, patchy lesions of Nocardia keratitis at six o'clock in a contact lens wearer had a BCVA of 20/40 or better and a median time from symptom onset to presentation of 10 days $(n=25$; range: $3-70$ days). The mean post-treatment BCVA $(n=21)$ was $20 / 40 \pm 2.7$ lines with a median treatment duration of 44 days ( $n=23$; range: $3-190$ days). A final post-treatment BCVA of $20 / 40$ or better was achieved in $71.4 \%(n=15 /$ 21) of patients. Overall, there was no significant difference in presenting versus last follow-up BCVA.

Contact lens wear was the leading identified risk factor for Nocardia keratitis among the study population (Table 1). A history of contact lens wear was present in $88.5 \% \quad(n=23 / 26)$ of patients; the remaining noncontact-lens cases were either associated with trauma. Trauma-related Nocardia keratitis was documented in $15.4 \%(n=4 / 26)$ of total cases. South Florida patients presenting with Nocardia keratitis were six times (23:4) more likely to be associated with contact lens wear than with trauma.

\section{Discussion}

The current study is the largest series to date on risk factors and amikacin-resistance among patient with Nocardia keratitis in the United States. The current series differs compared to reports from Asia by species diversity, risk factors, and amikacin susceptibility profiles $[5,7]$. Compared to the largest reported series from India $(n=116)$ [5], patients in this current series were younger, presented earlier, had better presenting/final BCVA, and healed faster.

The true prevalence of Nocardia keratitis in the United States is unknown, but prior to this study, only one series of three or more patients with Nocardia keratitis had been reported in the United States [9]. Hirst reported on a series of eight patients in 1979. Since then, only sporadic cases $(n=17)$ have been reported from 10 states and Washington DC [9-25]. Overall, 72\% $(n=18 / 25)$ have been reported from northern states with only six reported from southern states including Florida $(n=4)$, Georgia $(n=1)$, and Texas $(n=1)$. Nine of the $17(52.9 \%)$ reports have been contact-lens associated supporting the evolving epidemiology in other parts of the United States.

Nocardia amikacinitolerans was the predominant identified Nocardia species among South Florida isolates in the current study resulting in keratitis; this is the second reported case series worldwide. Among more than 200 Nocardia keratitis cases reported from South India in the last three decades, none have been identified as $N$. amikacinitolerans $[4,5,7]$.

Amikacin nonsusceptibility was found to be $64 \%$ in this case series. DeCroos and colleagues reported a resistance rate of 3\% for their 116 Nocardia keratitis isolates over an 11-year period [5]. Sporadic, but increasing amikacin resistance have been reported for a diverse group of 


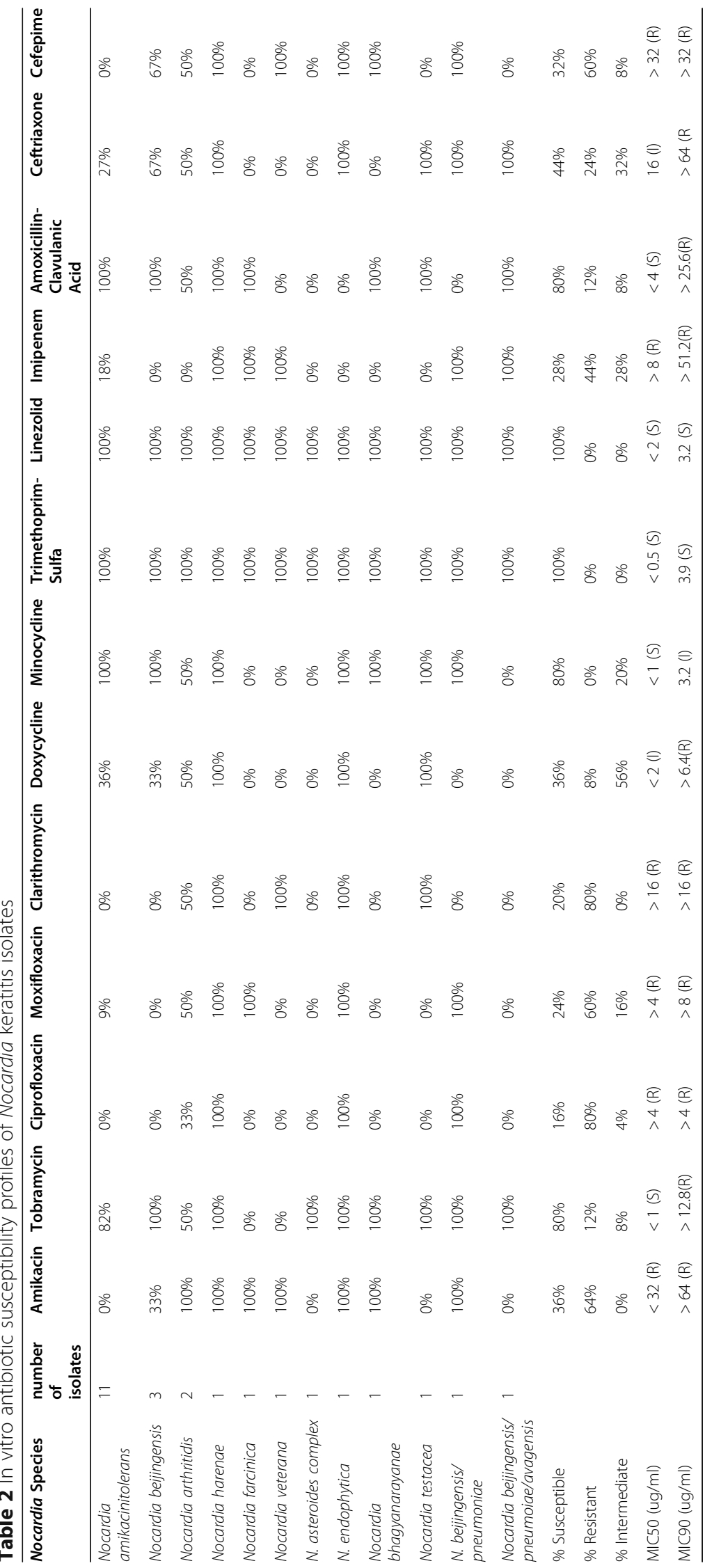


Nocardia keratitis isolates including $N$. tranvalensis [26], and members of the $N$. asteroides complex [24].

In vitro susceptibilities for Nocardia species are strain specific. It is important to run in vitro susceptibility testing to determine the most effective drugs for ocular Nocardia infections $[1,5,27,28]$. Based on in vitro data in this current study, trimethoprim sulfamethoxazole and linezolid demonstrated $100 \%$ susceptibility rates. Given its wider availability, trimethoprim sulfamethoxazole may be the preferred antibiotic agent in treating Nocardia keratitis and specifically, amikacin-resistant cases of Nocardia keratitis. Data from the Steroids for Corneal Ulcer Trial (SCUT) study confirmed the correlation between increasing drug minimal inhibitory concentrations and patient's outcomes.

Contact lens use was the leading risk factors identified among South Florida Nocardia keratitis patients. Contact lens wear was not a recognized risk factors among the 116 cases reported by DeCroos and colleagues nor among the 55 patients in the SCUT study [4]. However, contact lens associated Nocardia keratitis may be increasing worldwide and in the United States [28-30]. This infection should be considered with a higher index of suspicion in contact lens wearers with refractory corneal ulcers. Specific details regarding contact lens type or specific hygiene regimen surrounding contact lens use were unable to be determined in this study.

\section{Conclusion}

Nocardia keratitis is rare and its clinical presentation is diverse. Contact lens wear is the leading risk factor of Nocardia keratitis in South Florida and has been the most commonly associated risk factor in the United States for the last 10 years. First line therapy with amikacin alone may lead to clinical failure consider trimethoprim sulfamethoxazole. Early collaboration with a microbiology laboratory to speciate and perform susceptibility testing can lead to favorable visual outcomes.

\section{Abbreviations}

IRB: Institutional Review Board; BCVA: Best Corrected Visual Acuity; MIC: Minimal inhibitory concentration; SCUT: Steroids for Corneal Ulcer Trial

\section{Acknowledgements}

Not applicable.

\section{Authors' contributions}

EA collected and analyzed data, performed susceptibility testing, and significantly contributed to the writing of the manuscript. JMM performed microbiology and molecular testing. HD, AA, HF, GA, JMP provided major contributions to writing the manuscript. DM performed susceptibility testing, patient data collection and analysis, and significantly contributed to the writing of the manuscript. All authors read and approved the final manuscript.

\section{Funding}

This work was supported in part by NIH Center Core Grant P30EY014801, Research to Prevent Blindness- Unrestricted Grant (GR004596). The Edward D. and Janet K. Robson Foundation; Florida Lions Eye Bank and Beauty of Sight
Foundation; Gifts from Drs. H. W. Flynn Jr., K. R. Olsen, M. E. Hildebrandt, R. Urs and A. Furtado; Henri and Flore Lesieur Foundation (J.-M. Parel).

\section{Availability of data and materials}

The datasets used and analyzed during this study are available from the corresponding author on reasonable request.

\section{Declarations}

\section{Ethics approval and consent to participate}

Institutional Review Board (IRB) approval was obtained from the University of Miami Miller School of Medicine Sciences Subcommittee for the Protection of Human Subjects and the research adhered to the Tenets of the Declaration of Helsinki (IRB Protocol Study ID \#20070960).

\section{Consent for publication \\ Not applicable.}

\section{Competing interests}

The authors declare that they have no competing interests.

\section{Author details}

${ }^{1}$ University of Miami Miller School of Medicine, Miami, FL, USA. ${ }^{2}$ Ophthalmic Biophysics Center, Bascom Palmer Eye Institute, Department of Ophthalmology University of Miami Miller School of Medicine, Miami, FL, USA. ${ }^{3}$ Ocular Microbiology Laboratory, Anne Bates Leach Eye Center, Bascom Palmer Eye Institute, University of Miami Miller School of Medicine, McKnight Research Pavilions, Rm 103A, 1638 NW 10th Avenue, Miami, FL 33136, USA. ${ }^{4}$ Department of Ophthalmology, Bascom Palmer Eye Institute, University of Miami Miller School of Medicine, Miami, FL, USA.

Received: 4 November 2021 Accepted: 14 February 2022

Published online: 05 March 2022

\section{References}

1. Duggal SD, Chugh TD (2020) Nocardiosis: a neglected disease. Med Princ Pract 29(6):514-523. https://doi.org/10.1159/000508717

2. Sahay P, Maharana PK, Sharma N (2021) Nocardia keratitis. In: Infections of the Cornea and Conjunctiva. Springer nature Singapore Pte Itd, Singapore, pp 115-123

3. Somani SN, Moshirfar M (2021) Nocardia keratitis. StatPearls. StatPearls publishing, Treasure Island (FL)

4. Lalitha P, Srinivasan M, Rajaraman R, Ravindran M, Mascarenhas J, Priya JL, Sy A, Oldenburg CE, Ray KJ, Zegans ME, McLeod SD, Lietman TM, Acharya NR (2012) Nocardia keratitis: clinical course and effect of corticosteroids. Am J Ophthalmol 154(6):934-939.e931. https://doi.org/10.1016/j.ajo.2012.06.001

5. DeCroos FC, Garg P, Reddy AK, Sharma A, Krishnaiah S, Mungale M, Mruthyunjaya P. Hyderabad Endophthalmitis Research G (2011) Optimizing diagnosis and management of Nocardia keratitis, scleritis, and endophthalmitis: 11-year microbial and clinical overview. Ophthalmology 118(6):1193-1200. https://doi.org/10.1016/j.ophtha.2010.10.037

6. Garg P, Sharma S, Vemuganti GK, Ramamurthy B (2007) A cluster of Nocardia keratitis after LASIK. J Refract Surg 23(3):309-312. https://doi.org/1 0.3928/1081-597X-20070301-17

7. Lalitha P (2009) Nocardia keratitis. Curr Opin Ophthalmol 20(4):318-323. https://doi.org/10.1097/ICU.0b013e32832c3bcc

8. Woods GL B-EB, . Conville PS, et al Susceptibility testing of mycobacteria, Nocardiae, and other aerobic Actinomycetes, 2nd edition. Clinical and laboratory standards institute (CLSI), CLSI, Wayne, PA

9. Hirst LW, Harrison GK, Merz WG, Stark WJ (1979) Nocardia asteroides keratitis. Br J Ophthalmol 63(6):449-454. https://doi.org/10.1136/bjo.63.6.449

10. Hirst LW, Merz WG, Green WR (1982) Nocardia asteroides corneal ulcer. Am J Ophthalmol 94(1):123-124. https://doi.org/10.1016/0002-9394(82)90208-2

11. Donnenfeld ED, Cohen EJ, Barza M, Baum J (1985) Treatment of Nocardia keratitis with topical trimethoprim-sulfamethoxazole. Am J Ophthalmol 99(5):601-602. https://doi.org/10.1016/s0002-9394(14)77973-5

12. Enzenauer RW, Cornell FM, Brooke JD, Butler CE (1989) Nocardia asteroides keratitis: a case associated with soft contact lens wear. CLAO J 15(1):71-73

13. Parsons MR, Holland EJ, Agapitos PJ (1989) Nocardia asteroides keratitis associated with extended-wear soft contact lenses. Can J Ophthalmol 24(3): 120-122 
14. Perry HD, Nauheim JS, Donnenfeld ED (1989) Nocardia asteroides keratitis presenting as a persistent epithelial defect. Cornea 8(1):41-44. https://doi. org/10.1097/00003226-198903000-00007

15. Lin JC, Ward TP, Belyea DA, McEvoy P, Kramer KK (1997) Treatment of Nocardia asteroides keratitis with polyhexamethylene biguanide. Ophthalmology 104(8):1306-1311. https://doi.org/10.1016/s0161-6420(97)3 0143-2

16. Lee LH, Zaidman GW, Van Horn K (2001) Topical bactrim versus trimethoprim and sulfonamide against nocardia keratitis. Cornea 20(2):179182. https://doi.org/10.1097/00003226-200103000-00014

17. Sridhar MS, Cohen EJ, Rapuano CJ, Lister MA, Laibson PR (2002) Nocardia asteroides sclerokeratitis in a contact lens wearer. CLAO J 28(2):66-68

18. Patel NR, Reidy JJ, Gonzalez-Fernandez F (2005) Nocardia keratitis after laser in situ keratomileusis: clinicopathologic correlation. J Cataract Refract Surg 31(10):2012-2015. https://doi.org/10.1016/j.jcrs.2005.02.049

19. Galor A, Hall GS, Procop GW, Tuohy M, Millstein ME, Jeng BH (2007) Rapid species determination of Nocardia keratitis using pyrosequencing technology. Am J Ophthalmol 143(1):182-183. https://doi.org/10.1016/j.ajo.2 006.07.036

20. Patel R, Sise A, Al-Mohtaseb Z, Garcia N, Aziz H, Amescua G, Pantanelli SM (2015) Nocardia asteroides keratitis resistant to amikacin. Cornea 34(12): 1617-1619. https://doi.org/10.1097//CO.0000000000000634

21. Shah P, Zhu D, Culbertson WW (2017) Therapeutic femtosecond laserassisted lamellar keratectomy for multidrug-resistant Nocardia keratitis. Cornea 36(11):1429-1431. https://doi.org/10.1097//CO.0000000000001318

22. Gieger A, Waller S, Pasternak J (2017) Nocardia arthritidis keratitis: case report and review of the literature. Nepal J Ophthalmol 9(1):91-94. https:// doi.org/10.3126/nepjoph.v9i1.17543

23. Siddiqui B, Vazquez J (2020) Corneal ulceration post-Lasik due to Nocardia veterana: case report and review. IDCases 19:e00672. https://doi.org/10.10 6/j.idcr.2019.e00672

24. Chang EL, Chu RL, Wittpenn JR, Perry HD (2021) Nocardia keratitis mimicking superior limbic keratoconjunctivitis and herpes simplex virus. Am J Ophthalmol Case Rep 22:101030. https://doi.org/10.1016/j.ajoc.2021.101030

25. Verner A, Durrani A, Kowalski RP, Jhanji V (2020) A case of Nocardia farcinica keratitis in a pediatric contact Lens wearer. Eye Contact Lens 46(2):e11-e12. https://doi.org/10.1097//CL.0000000000000594

26. Trichet E, Cohen-Bacrie S, Conrath J, Drancourt M, Hoffart L (2011) Nocardia transvalensis keratitis: an emerging pathology among travelers returning from Asia. BMC Infect Dis 11(1):296. https:/doi.org/10.1186/1471-2334-11-296

27. Hamdi AM, Fida M, Deml SM, Abu Saleh OM, Wengenack NL (2020) Retrospective analysis of antimicrobial susceptibility profiles of Nocardia species from a tertiary hospital and reference laboratory, 2011 to 2017. Antimicrob Agents Chemother 64(3):e01868-19. https://doi.org/10.1128/AAC. 01868-19

28. Johansson B, Fagerholm P, Petranyi G, Claesson Armitage M, Lagali N (2017) Diagnostic and therapeutic challenges in a case of amikacin-resistant Nocardia keratitis. Acta Ophthalmol 95(1):103-105. https://doi.org/10.1111/a os.13182

29. Behaegel J, Ni Dhubhghaill S, Koppen C (2018) Diagnostic challenges in Nocardia keratitis. Eye Contact Lens 44(Suppl 1):S370-S372. https://doi.org/1 $0.1097 /$ ICL.0000000000000462

30. Hoffman PM, Poon A, Snibson GR (2005) Nocardia keratitis in a contact lens wearer. Arch Ophthalmol 123(12):1759. https://doi.org/10.1001/a rchopht.123.12.1759

\section{Publisher's Note}

Springer Nature remains neutral with regard to jurisdictional claims in published maps and institutional affiliations.

\section{Submit your manuscript to a SpringerOpen ${ }^{\circ}$ journal and benefit from:}

- Convenient online submission

- Rigorous peer review

- Open access: articles freely available online

- High visibility within the field

- Retaining the copyright to your article

Submit your next manuscript at $\boldsymbol{\nabla}$ springeropen.com 